\title{
Experience in inspection of operated rural school buildings
}

\author{
Nina Buzalo, Irina Platonova, Nadezhda Tsaritova*, Igor Kosogov \\ Platov South-Russian State Polytechnic University (NPI), 346428, Novocherkassk, Russia
}

\begin{abstract}
Summarizing the experience of examining school buildings built in rural areas in 1950 - 1990, the article draws conclusions about their technical condition and compliance with the requirements of modern regulatory documents. All surveyed school buildings do not meet the requirements for resistance to heat transfer of enclosing structures, accessibility for all categories of low-mobile groups of the population. The article presents the results of a survey of a high school building in the Oblivsky district of the Rostov region and a high school building in the village of Karaichevskaya in the Rostov region, high school building in the Kuibyshev district of the Rostov region. A number of defects and damages were found in the buildings under investigation. The analysis of the experience of survey of school buildings located in rural areas of the Rostov region.
\end{abstract}

\section{Introduction}

According to statistical data [1], there are currently 41300 schools in the Russian Federation (organizations that carry out educational activities in accordance with the educational programs of primary, basic and secondary General education).

The number of schools has changed significantly in recent years. The result of the optimization carried out by the Ministry of education was a reduction in the number of rural schools - from 39 to 24 thousand, urban — from 24 to 18 thousand units. This led to an increase in the number of students forced to work in the second and third shifts (table 1). According to Rosstat [1], in the 2018/19 academic year, 1.2 million students in grades 1-4 (17.4\% of their total number), 782 thousand students in grades 5-9 (10.7\%) and about 10 thousand high school students $(0.7 \%)$ were employed in the second and third shifts. At the same time, the number of school children is expected to increase to almost 20 million by 2024.

Table 1.

\begin{tabular}{|l|c|c|c|c|c|}
\hline & $2006 / 2006$ & $2010 / 2011$ & $2016 / 2017$ & $2017 / 2018$ & $2018 / 2019$ \\
\hline $\begin{array}{l}\text { Number of } \\
\text { schools (at the } \\
\text { beginning of the }\end{array}$ & 63.2 & 50.8 & 41.8 & 42.0 & 41.3 \\
\hline
\end{tabular}

${ }^{*}$ Corresponding author: ncaritova@yandex.ru 


\begin{tabular}{|l|l|l|l|l|l|}
\hline $\begin{array}{l}\text { school year), } \\
\text { thousand units }\end{array}$ & & & & & \\
\hline $\begin{array}{l}\text { The number of } \\
\text { students enrolled } \\
\text { in educational } \\
\text { programs of } \\
\text { primary, basic } \\
\text { and secondary }\end{array}$ & 15630.9 & 13642.4 & 15219 & 15705.9 & 16137.3 \\
$\begin{array}{l}\text { General } \\
\text { education, } \\
\text { thousand people. }\end{array}$ & & & & & \\
\hline $\begin{array}{l}\text { Number of } \\
\text { students } \\
\text { employed in the } \\
\text { first shift, million } \\
\text { people. }\end{array}$ & 12.5 & 11.2 & 12.8 & 13.3 & 13.6 \\
\hline $\begin{array}{l}\text { Number of } \\
\text { students } \\
\text { employed in the } \\
\text { second and third } \\
\text { shifts, million } \\
\text { people. }\end{array}$ & & & & & \\
\hline
\end{tabular}

\section{Materials and Methods}

In the 1960s and 70s, when designing and building school buildings, urban planning policy [2] set the goal first of all to transfer schools to single-shift classes and count classes for 40 people, and then to convert schools to extended-day schools with a reduction in the number of students in the class to 25-30 people. For this purpose, it was proposed to use standard designs of school buildings for 280, 520 and 960 places, depending on the nature and methods of development of cities and working settlements. Schools with a capacity of less than 960 seats were designed for small towns and cities. For large cities, projects were developed for standard schools with a capacity of 960 and 1280 places with a population of 6-8 thousand people in the micro district; with a population of 9-12 thousand people, it was proposed to build schools for 1600 places. "The enlargement of school buildings is designed to create more favorable conditions for the educational process (it is possible to place production workshops, sports complexes, etc.) and improve the technical and economic indicators of buildings," he said half a century ago [2]. When choosing the type of school buildings in specific conditions, it was suggested that buildings with a larger capacity should be preferred, which are more economical in terms of construction costs. It was also planned to place boarding schools with a capacity of 320 and 560 places in cities or working-class settlements serving nearby small settlements where it is not advisable to create secondary schools due to the insufficient number of school-age children. This fully complies with modern regulatory requirements [3] on the availability of boarding schools in rural areas in the amount of $10 \%$ of the total capacity of an educational organization if the standard time of transport accessibility is exceeded.

Between 2000 and 2018, 26,000 schools were closed in the Russian Federation, 20,000 of them in rural areas. On April 30, 2014, the government adopted a resolution "on changes in the social sphere and improving the efficiency of educational institutions". According to 
this document, if the regional authorities recognize an educational institution as ineffective, it will be liquidated.

The effectiveness of a school is determined by many parameters, but not least is the physical and moral deterioration of school buildings.

Compositionally, in domestic practice, the centralized block type was mainly used, which formed the basis of standard solutions for school buildings built in 1950-2000 [4, 5, 6]. This type of composition allows you to divide blocks by functional characteristics, differentiate students by age, and also provides an opportunity for the development of the school complex. To increase the economic efficiency of school buildings, the goal was to use capital reinforced concrete and brick load-bearing structures during construction.

The past decades allow us to analyze how successful the solutions included in the concept of design and construction of school buildings were, using the example of rural schools. The article uses materials from surveys of rural schools in the Rostov region conducted in 2016-2018.

\section{Results}

\subsection{The result of the survey of the building of a secondary school in the Oblivsky district of the Rostov region}

The building of a secondary school in Oblivsky district of the Rostov region with a total area of about $2000 \mathrm{~m}^{2}$ consists of three buildings connected by covered passages. The blocks differ structurally and functionally. The building of the "old" school - block 1 (Fig. 1), built in 1940, accommodates classrooms and boarding facilities.

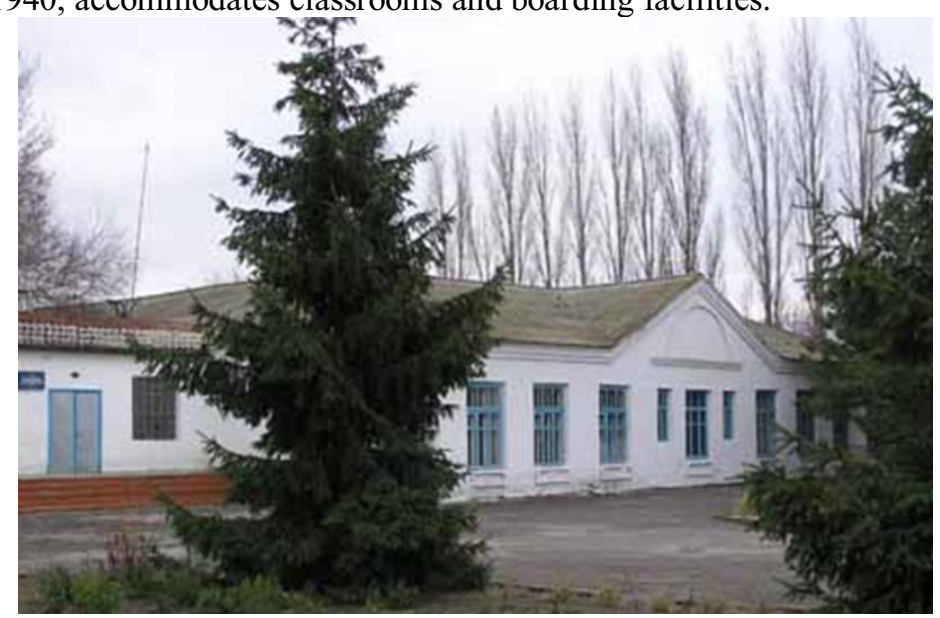

Fig. 1. The building of the "old" school.

Block 2 (Figure 2) contains administrative offices and classrooms, while block 3 contains a gym, military training class, and utility rooms. Blocks 2 and 3, connected to each other and to block 1 by covered walkways, were built and commissioned in 1987 as part of the expansion of the school complex.

The foundations of block 1 (the "old" school building) are made of rubble strips supporting aboveground structures-longitudinal and transverse walls of clay bricks with a thickness of $510 \mathrm{~mm}$ (external) and $380 \mathrm{~mm}$ (Internal). The internal surfaces of walls and brick partitions $120 \mathrm{~mm}$ thick are plastered with clay mortar. 


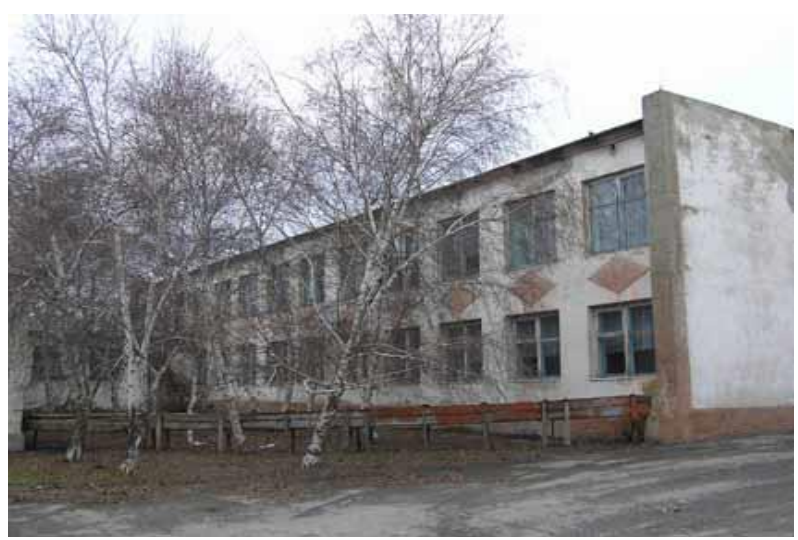

Fig. 2. Block 2 of the training complex.

The lintels above the window and door openings are made of wooden beams. Cover the attic with wooden beams. The ceilings are boarded and plastered with tiles and clay mortar. The roof is four-pitched from asbestos-cement wavy sheets on a wooden box.

Block 2 foundations - rubble concrete and supporting aboveground structures longitudinal walls made of clay bricks with a thickness of $510 \mathrm{~mm}$. The external and internal surfaces of the walls are plastered with cement-lime mortar. $120 \mathrm{~mm}$ thick brick walls. the lintels over the window and door openings are reinforced concrete, factory-made. The building's floor coverings are made of reinforced concrete multi-hollow slabs of the 1.141-1 series. Stairs made of reinforced concrete, supported on a reinforced concrete slab platform. The surface is flat on reinforced concrete slabs. The roof of the building is made of rolled roofing material on bituminous mastic with expanded clay insulation. Drainage from the roof is not organized in the direction of the external longitudinal walls of the Eastern and Western facades.

The foundations of block 3 are a strip of rubble concrete that supports aboveground structures - longitudinal walls made of clay bricks with a thickness of $510 \mathrm{~mm}$, reinforced with pilasters at the points where the edges of the coating plates stop. In the upper part of the walls of the gym, a monolithic reinforced concrete belt is arranged, in which embedded plates are fixed for fixing the coating plates. The external and internal surfaces of the walls are plastered with cement-lime mortar. The walls are made of bricks with a thickness of $120 \mathrm{~mm}$. The lintels over the window and door openings are made of factory reinforced concrete and rolled steel. The inter-storey floors in the two-storey part of the building are made of reinforced concrete multi-hollow slabs of the 1.141-1 series. The staircase is made of reinforced concrete and rests on a reinforced concrete platform slab. The surface is flat on reinforced concrete slabs, the design of the two-story part is similar to the overlap of multi-hollow slabs according to the scheme 1.141-1. The gym floor is made of ribbed reinforced concrete slabs with prestressed reinforcement. The roof of the building is made of rolled roofing material on bituminous mastic with expanded clay insulation. Drainage from the roof is not organized in the direction of the external longitudinal walls of the southern and Northern facades.

Examination of the school complex revealed a number of defects and damages[7, 8], the main of which are through cracks 2-3 mm wide opening in the gym wall (Fig. 3), defects in external masonry and plaster associated with atmospheric influences, which include thawed and destroyed local sections of plaster and masonry walls to a depth of $100 \mathrm{~mm}$ (Fig. 4) cracks of various lengths and widths of the opening above the openings of the external walls of block 1 (Fig. 5). 

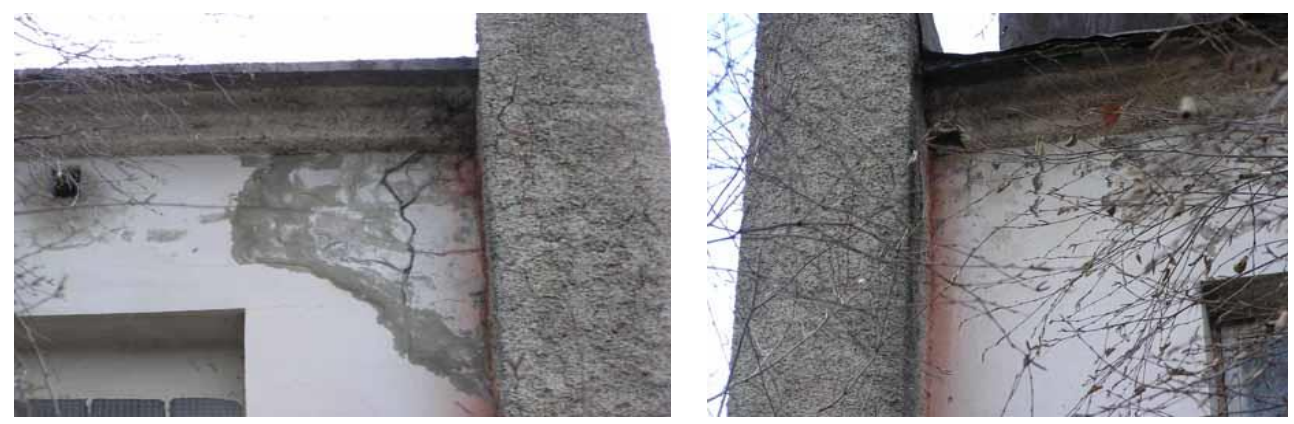

Fig. 3. Through cracks $2-3 \mathrm{~mm}$ wide in block 3 of the school complex.

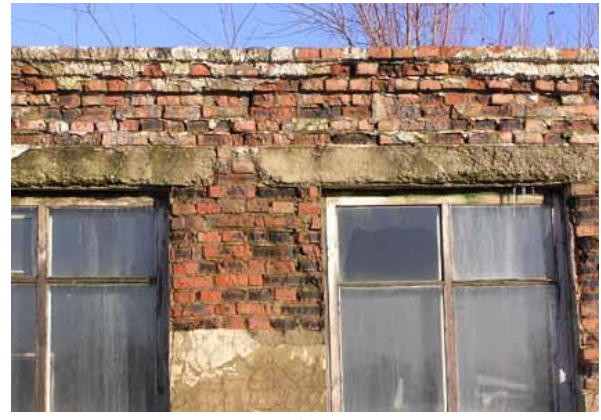

a)

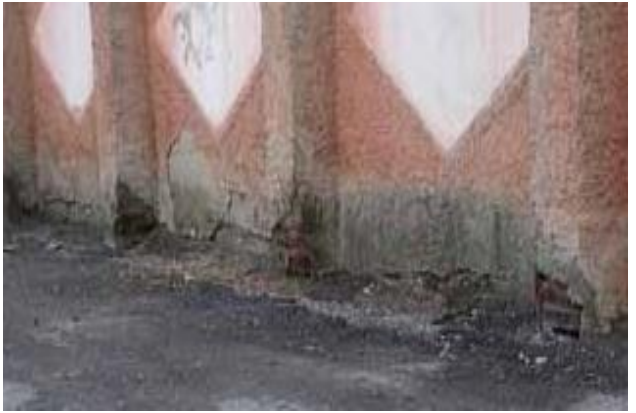

b)

Fig. 4. a) thawed and destroyed to a considerable depth sections of external brick walls; b) destroyed pilasters in the wall of the gym in those places where the blind area is adjacent.

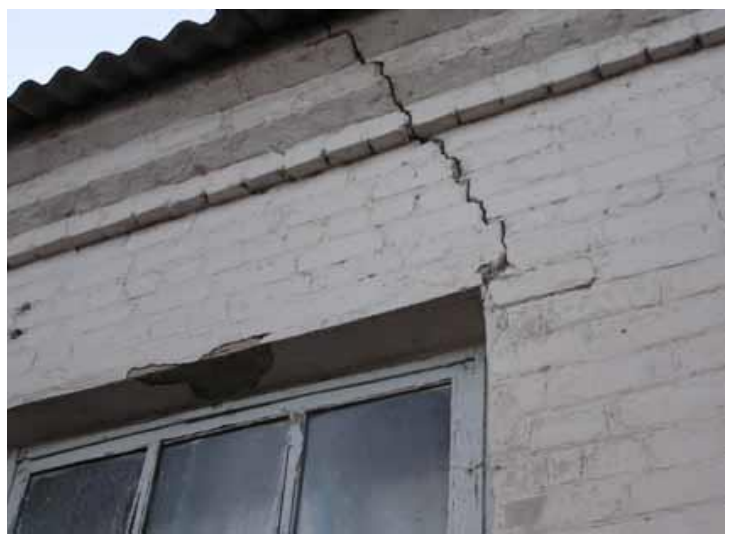

Fig. 5. Cracks above the aperture in block 1.

\subsection{The result of the survey of the high school building in the Kuibyshev district of the Rostov region}

The high school building in the Kuibyshev district of the Rostov region, built in 1989, is a two-story building with a ground floor and has a T-shape with dimensions of $42.0 \times 54.0 \mathrm{~m}$ in plan (Fig. 6). In addition to training halls, the building has a training and game rooms. The game room on the +4100 level has a built-in second level (balcony). The total area of the building is $2917.3 \mathrm{~m} 2$. The construction volume is $9440 \mathrm{~m} 3$. 
The building foundations for brick walls with pilasters are made of columns with Foundation beams according to the 1.415-1 series, as well as precast concrete blocks along a monolithic reinforced concrete belt. Foundations for load-bearing brick walls are made of precast concrete blocks on Foundation slabs of the 1.122-1 series.

According to the design scheme, the building is made with load-bearing external and internal longitudinal and transverse brick walls made of ceramic bricks on cement - sand mortar, precast concrete floors and coatings external and internal walls and partitions are made of ceramic bricks on cement - sand mortar with a thickness of: external walls -510 $\mathrm{mm}$, Internal-380 $\mathrm{mm}$, partitions- $120 \mathrm{~mm}$.

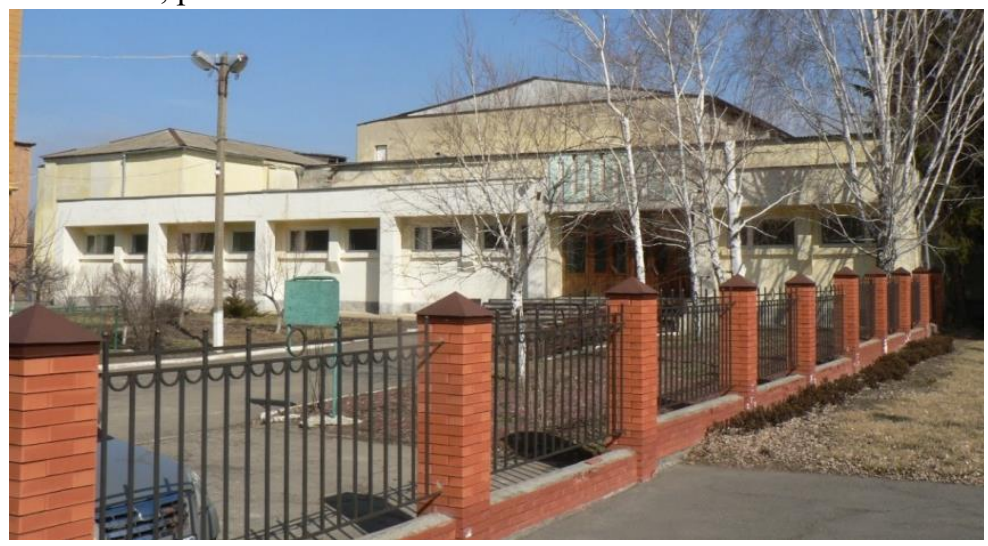

Fig. 6. General view of the school building in the Kuibyshev district of the Rostov region.

During the operation of the building, due to prolonged soaking of subsidence soils located at the base of the foundations, uneven deformations occurred, as evidenced by cracks in the load-bearing walls with varying degrees of disclosure. The reason for uneven deformations of Foundation soils is their soaking due to the partial destruction of the blind area around the perimeter of the building and leaks from engineering communications (Fig. $8)$.

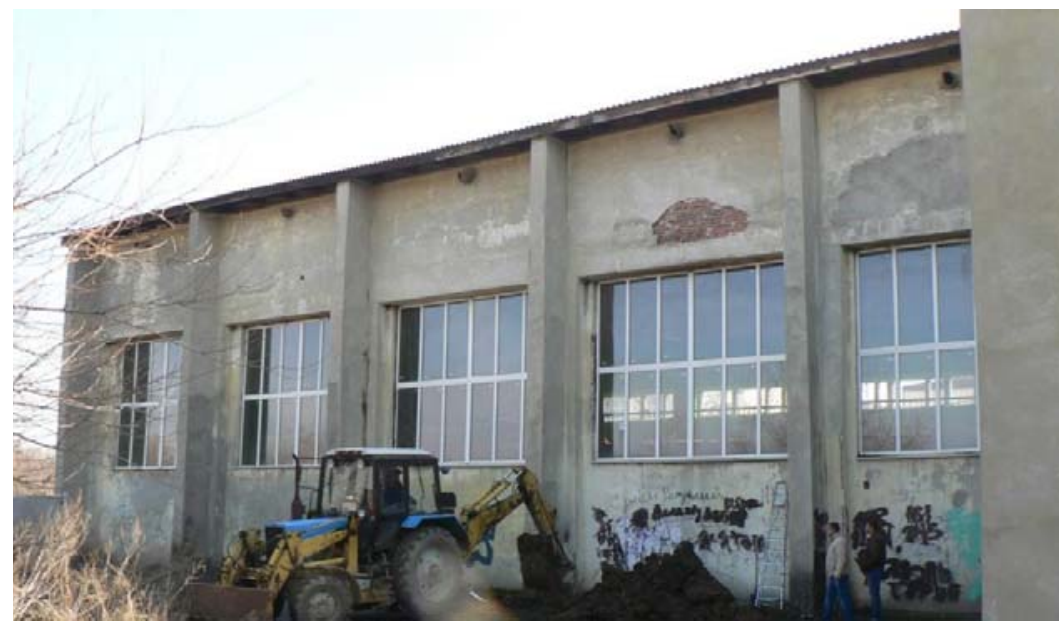

Fig. 7. State of load-bearing structures of the game hall.

The floors and surface of the building are made of precast concrete slabs and monolithic profiles of various sizes on reinforced concrete and metal beams (Fig. 8). 


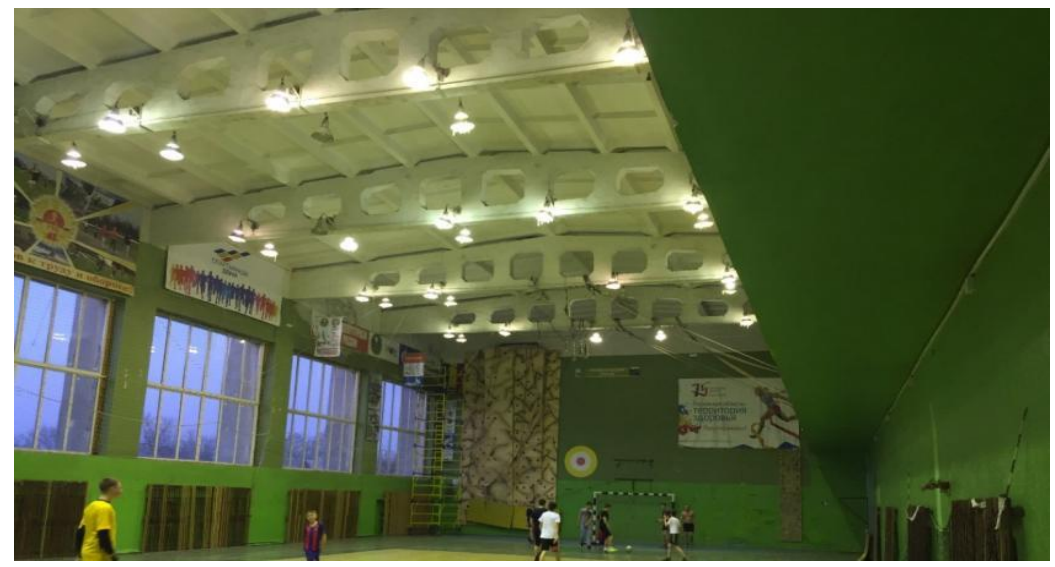

Fig. 8. School game hall with load-bearing structures made of precast concrete structures.

\subsection{Survey of the building of a secondary school in the village of Karachevskaya Oblivsky district of the Rostov region}

The secondary school building in the village of Karachevskaya in the Oblivsky district of the Rostov region has a complex configuration with overall dimensions of $51.86 \times 21.15 \mathrm{~m}$ (Fig. 9). The building is two-storeyed with the built-in one-storeyed (in two lamps) gym, in a zone of a stairwell there is a technological underground $8.0 \mathrm{~m}$ long in which inputs of communications and a heat node are located. The total height of the building is $6.9 \mathrm{~m}$ with the height of the first and second floors $3.0 \mathrm{~m}$.

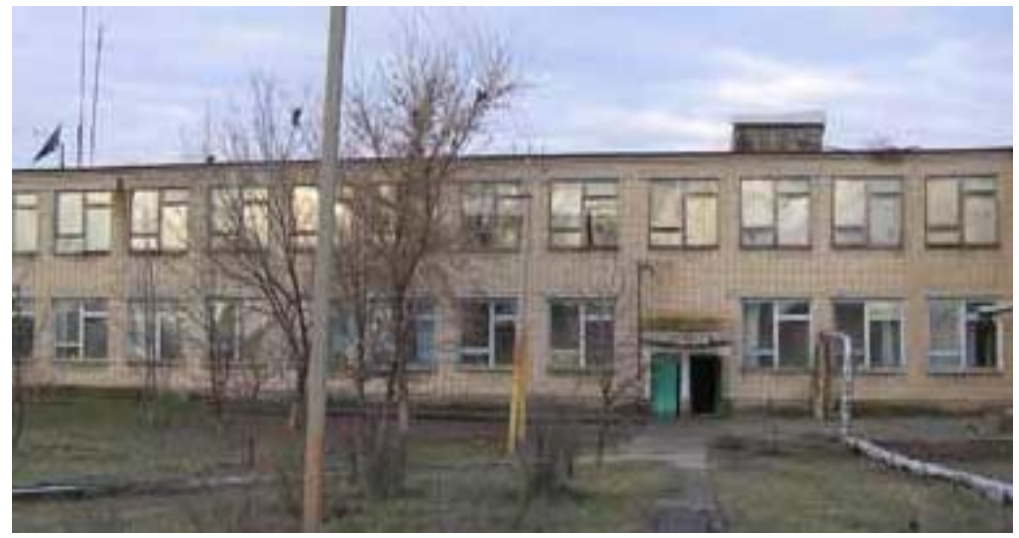

Fig. 9. Facade of the school building in the village of Karachevsky

The foundations of the building are made of ribbon rubble concrete, supporting aboveground structures - longitudinal and transverse walls made of silicate bricks with a thickness of $380 \mathrm{~mm}$ and $510 \mathrm{~mm}$, and the walls of the gym are reinforced with pilasters at the points where the roof beams are supported. The internal surfaces of the walls are plastered with cement-lime mortar. $120 \mathrm{~mm}$ thick brick walls. the lintels above the window and door openings are made of factory reinforced concrete.

The building's floor coverings are made of reinforced concrete multi-hollow slabs of the 1.141-1 series. Stairs are reinforced concrete, supported by reinforced concrete platform slabs. 
Covering of flat hollow slabs of the 1.141-1 series in the two-story part and ribbed slabs of the 1.165-6 series in the one-story part (sports hall), supported by end walls and beams of reinforced concrete $\mathrm{T}$-section.

The main defects and damages identified during the survey are cracks of various lengths and widths of opening caused by uneven deformations of foundations in places of systematic soaking of Foundation soils (Fig. 10), thawed and destroyed local sections of walls, low strength of cement-sand mortar in masonry joints.

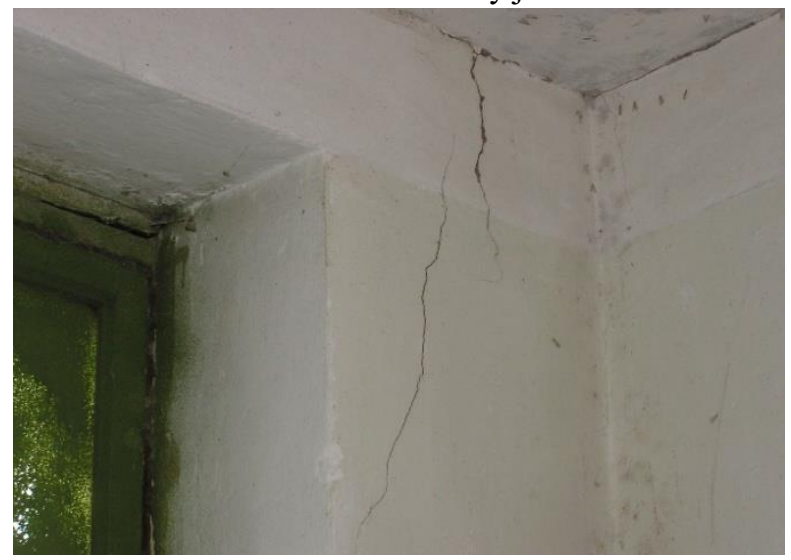

Fig. 10. crack above the 2nd floor window opening.

\section{Conclusions}

Analyzing the experience of examining school buildings located in rural areas of the Rostov region, we can draw a number of conclusions:

1. Using a centralized block-type composite solution for school buildings allows you to expand school complexes, if necessary, by adding educational and sports blocks, workshops, and premises for boarding schools connected by covered walkways. In addition, it is functionally justified to place students of different ages in different blocks of the building, create production workshops, boarding schools, etc.in separate blocks.

2. The use of factory reinforced concrete floors, coverings, lintels, staircases and platforms in the construction of school buildings allowed to avoid damage to this type of structures. Load-bearing brick walls, cornices and parapets usually have widespread damage in the form of soaking, thawing and destruction of brickwork, as well as peeling and destruction of external plaster, cracks caused by Foundation precipitation. The reason for damage to brick walls is the poor quality of the mortar and bricks used in masonry, systematic soaking of masonry, due to the unsatisfactory condition of roofs, lack of organized drainage. The presence of cracks in the masonry is caused by soaking of subsidence soils of the bases of strip foundations due to leaks of engineering communications and damage to the blind area.

3. In all surveyed school buildings, the external brick walls have a thickness of $510 \mathrm{~mm}$, which does not meet the requirements [9] for heat transfer resistance of enclosing structures.

4. All surveyed school buildings do not meet the accessibility requirements for all categories of people with limited mobility [10] in all major structural and functional areas (the territory adjacent to the building, the entrance to the building, transport routes inside the building, the target area of the building, sanitary facilities, information and communication system, transport routes to the object). 
5. When the condition survey of the adjoining territory of school complexes in all cases showed local destruction of blind area around the perimeter of the buildings and the gaps of the blind area in close proximity to the walls of buildings in the input places of communication. It is necessary to ensure the supply of external communications, ensure the tightness of the inputs, restore the blind area, perform landscaping of the surrounding area, including the removal of vegetation located near buildings.

6. Most existing school buildings can and should be reconstructed $[11,12]$ and used for their intended purpose for conducting classes in one shift, providing children with school meals and additional education (clubs, production workshops, vocational schools, sports sections) in the afternoon.

In rural areas, on the basis of existing school complexes, after reconstruction, it is possible to create sanatorium-forest schools, boarding schools for advanced education of children, special boarding schools for children with physical and mental disabilities.

\section{References}

1. Russia in numbers, Krat. stat. (SB./Rosstat,Moscow, 2019).

2. Fundamentals of Soviet urban planning. Volume 2/ Central research and design Institute for urban planning (SI, Moscow, 1965).

3. SP 42.13330.2016 Urban planning. Planning and development of urban and rural settlements.

4. A.V. Zakharov, Architecture of civil and industrial buildings: civil buildings: Study.stipend. For universities (SI, Moscow, 1993).

5. P.G. Grabovogo, V. A. Kharitonova, Reconstruction and renewal of existing buildings in the city. Textbook for universities (Publishing house "DIA" and "Realproekt", Moscow, 2006).

6. V.V. Sawilowsky, V.N. Bolotsky, The repair and reconstruction of civil buildings (Publisher: publishing house "Waterpass", Kharkiv, 1999).

7. I.A. Fizdel, Defects in the designs, structures and methods of their elimination (Stroizdat, Moscow, 1987).

8. L. Hikes, Repair and maintenance of residential buildings. Reference guide (Stroyizdat, Moscow, 1992).

9. BC 50.13330.2012 Thermal protection of buildings. Updated version of BC 23-022003 (with change N 1)

10. BC 59.13330.2016 Accessibility of buildings and structures for people with limited mobility. Updated version of BC 35-01-2001.

11. A.L. Shagin, Yu.V. Bondarenko, D. F. Goncharenko, V. B. Goncharov, Reconstruction of buildings and structures (Higher school, Moscow, 1991).

12. Claus Arendt, Altbausanierung, DeutcheVerkags-AristaltStuttgart. 1996. 